\title{
PEMBATASAN-PEMBATASAN KONSTITUSIONAL KEKUASAAN PRESIDEN SESUDAH PERUBAHAN UUD 1945
}

\author{
Soenobo Wiryosoegito ${ }^{1}$ \\ Noer Indriati ${ }^{2}$ \\ Fakultas Hukum Universitas Jenderal Soedirman \\ Email: indriatiyuwanto@yahoo.co.id
}

\begin{abstract}
The slide down of President Soeharto in 1998, then turned mainly to the reform scedule of changes or amendments to the Constitution. After the change of Constitution occurring shift of power from the hands of the President of the legislation to the House of Representative. The powers of the President of the much reduced, for example: Judges no longer appointed by the President, but rather put forward by the Commission for the requested Judicial House approval, further defined by the President. Power House were enlarged in such a way, so that it can be said almost all fields of power President entered by Parliament.
\end{abstract}

Keywords: limitations, the power of President and Parliamen

\begin{abstract}
Abstrak
Lengsernya Presiden Soeharto pada tahun 1998, maka agenda reformasi terutama tertuju kepada perubahan atau amandemen UUD 1945. Sesudah perubahan UUD 1945 terjadi pergeseran kekuasaan legislasi dari tangan Presiden ke DPR. Kekuasaan Presiden banyak dikurangi, misalnya: Hakim Agung tidak lagi diangkat oleh Presiden, melainkan diajukan oleh Komisi Yudisial untuk diminta persetujuan DPR, selanjutnya ditetapkan oleh Presiden. Kekuasaan DPR diperbesar sedemikian rupa, sehingga dapat dikatakan hampir semua bidang kekuasaan Presiden dimasuki oleh DPR.
\end{abstract}

Kata kunci: Pembatasan-pembatasan, Kekuasaan Presiden, DPR

\section{PENDAHULUAN}

Pada saat ini Undang-Undang Dasar (selanjutnya disingkat UUD) 1945 sudah mengalami perubahan yang sangat mendasar. Perubahan pertama dimulai pada tahun 1999 dan seterusnya berturut-turut sampai dengan perubahan keempat pada tahun 2002. Bermula dari gagasan untuk mengadakan pembatasan kekuasaan dan masa jabatan Presiden. Hal ini dapat dipahami, karena masyarakat melihat pengalaman pemerintahan masa lalu yang lebih didominasi oleh kekuasaan Presiden. $^{3}$
Sebagaimana kita telah maklum karena tidak adanya pembatasan masa jabatan Presiden itu, Jenderal Soeharto dapat dipilih sampai 6 (enam) kali berturut-turut sebagai Presiden Republik Indonesia (1971-1998)

Berkaitan dengan hal itu, Denny Indrayana dalam kitab ujianya mengemukakan, ${ }^{4}$ bahwa UUD 1945 adalah sebuah konstitusi yang "sarat eksekutif'. Ini berarti bahwa konstitusi ini memberikan begitu banyak kekuasaan kepada ekskutif, tanpa menyertakan sistem kontrol konstitusional yang memadai. Dikatakan, bahwa di bawah UUD 1945

Pensiunan Dosen FH Universitas Sultan Agung, Semarang

Dosen tetap Fakultas Hukum Unsoed, e-mail: indriatiyuwanto@yahoo.co.id

Taufiqurrohman Syahuri, Hukum Konstitusi, Ghalia Indonesia, Jakarta, 2004, hal. 2

Denny Indrayana, Amandemen UUD 1945, PT.Mizan Pustaka, Bandung, 2007, hal. 152 
Presiden adalah kepala pemerintahan atau eksekutif dan Kepala Negara. Pada praktiknya kekuasaan Presiden yang luas dan sebagian besar tak terkontrol ini digunakan oleh Soeharto sebagai landasan hukum untuk memilih orang pilihannya untuk menduduki posisi strategis. Tak heran kalau Presiden Soeharto berhasil mengendalikan Birokrasi, Militer, Lembaga Legislatif dan Yudikatif.

Pada tanggal 21 Mei 1998 telah terjadi perubahan, Soeharto mengundurkan diri sebagai Presiden Republik Indonesia dan digantikan oleh Presiden B.J. Habibie. Bersamaan waktu itu muncullah tuntutan masyarakat luas untuk melakukan perubahan (amandemen) UUD 1945 menuju kepada konstitusi yang demokratis sebagai salah satu agenda reformasi. Dalam pada itu Jimly Asshiddiqie mengemukakan pendapatnya, bahwa reformasi politik dan ekonomi yang bersifat menyeluruh tidak mungkin dilakukan tanpa diiringi reformasi hukum. Akan tetapi reformasi hukum yang menyeluruh juga tidak mungkin dilakukan tanpa didasari oleh agenda reformasi ketatanegaraaan yang mendasar, dan itu berarti diperlukan adanya "constitutional reform" yang tidak setengah hati. ${ }^{5}$

Selanjutnya dengan lengsernya Presiden Soeharto pada tahun 1998, agenda reformasi terutama tertuju kepada perubahan atau amandemen UUD 1945.

\section{RUMUSAN MASALAH}

Di dalam tulisan ini akan membahas "Pembatasan-pembatasan Konstitusional kekuasaan Presiden Sesudah Perubahan UUD 1945".
Sejauh mana perubahan UUD 1945 itu mengurangi kekuasaan Presiden?

\section{PEMBAHASAN}

\section{Kekuasaan Presiden}

Sebelum perubahan UUD 1945, Presiden dipilih oleh Majelis Permusyawaratan Rakyat (MPR). Pasal 6 ayat (2) UUD 1945 menyebutkan: Presiden dan Wakil Presiden dipilih oleh Majelis Permusyawaratan Rakyat, dengan suara terbanyak. Penjelasan UUD 1945 menerangkan bahwa: Majelis inilah yang memegang kekuasaan negara yang tertinggi, sedang Presiden harus menjalankan Haluan Negara menurut garis-garis besar yang telah ditetapkan oleh Majelis. Presiden yang diangkat oleh Majelis, bertindak bertangung jawab kepada Majelis, di bawah Majelis Presiden ialah penyelenggara pemerintahan negara yang tertinggi. Dalam menjalankan pemerintahan kekuasaan dan tanggung jawab ialah ditangan Presiden (Concentration Of Power and Responsibility Upon the President).

Sebelum perubahan UUD 1945 kekuasaan Presiden diatur dalam Bab III Kekuasaan Pemerintah Negara. Bab ini meliputi Pasal-pasal 4, 5, 6, 7, 8, 9, 10, 11, 12, 13, 14, 15 dan 17 ditambah Pasal 22. Selain itu masih ada wewenang Presiden yang berkaitan dengan masalah lain, seperti: Penetapan APBN, menyelenggarakan sistem pengajaran, memajukan kebudayaan nasional, dll.

Masih sebelum perubahan UUD 1945, Pasal 4 ayat (1) menyatakan bahwa Presiden Republik Indonesia memegang kekuasaan pemerintahan menurut UUD. Menurut UUD maka kekuasaan pe-

\footnotetext{
${ }^{5}$ Sekapur Sirih Vide Taufiqurrohman Syahuri, loc. Cit.
} 
merintahan dan kekuasaan administrasi diletakkan disatu tangan Presiden. ${ }^{6}$ Dalam pada itu Prajudi Atmosudirjo menjelaskan bahwa Administrasi Negara Republik Indonesia itu dijalankan oleh Presiden sebagai Pemerintah, merangkap sebagai Administrator Negara dengan memimpin dan mengepalai suatu Aparatur Negara yang besar sekali juga yang disebut Administrasi Negara. ${ }^{7}$ Kemudian selanjutnya dengan menunjuk Pasal 17 UUD 1945, R. Wiyono membuat kesimpulan, ${ }^{8}$ bahwa kekuasaan Presidensial di lapangan tata usaha pemerintahan atau administrasi adalah mengkoordinasi dan mengawasi tugas-tugas yang dijalankan oleh para menteri.

Sebagaimana telah diketahui, dalam menjalankan tugasnya itu Presiden dibantu selain oleh Wakil Presiden juga oleh Menteri-menteri Negara. Menteri-menteri ini masing-masing memimpin Departemen Pemerintahan.

Dalam pada itu Bagir Manan mengemukakan pendapatnya, bahwa ditinjau dari teori pembagian kekuasaan, yang dimaksud kekuasaan pemerintahan adalah kekuasaan eksekutif. ${ }^{9}$ Dikatakan sebagai kekuasaan eksekutif, penyelenggaraan pemerintahan yang dilaksanakan Presiden dapat dibedakan antara: kekuasaan penyelenggaraan pemerintahan yang bersifat umum, dan kekuasaan penyelenggaraan pemerintahan yang bersifat khusus. Kekuasaan penyelenggaraan pemerintahan yang bersifat umum adalah penyelenggaraan administrasi negara. Presiden adalah

6 Moh. Kusnardi dan Bintan R Saragih, Susunan Pembagian Kekuasaan Menurut UUD 1945, Gramedia, Jakarta, 1978, hal. 62

7 Prajudi Atmosudirjo, Dasar-Dasar ilmu Administrasi, Cetakan ke 7, Jakarta, hal.273

8 R.Wiyono, Garis-Garis Besar Pembahasan dan Komentar UUD 1945, Alumni, Bandung, 1982, hal.61 pimpinan penyelenggaraan administrasi negara tertinggi. Penyelenggaraan administrasi negara meliputi lingkup tugas dan wewenang ini makin meluas sejalan dengan makin meluasnya tugastugas dan wewenang negara dan pemerintah. Lebih lanjut tugas dan wewenang tersebut dikelompokan sebagai berikut:

a. Di bidang keamanan dan ketertiban umum;

b. Menyelenggarakan tata usaha pemerintahan;

c. Di bidang pelayanan umum; dan

d. Di bidang penyelenggaran kesejahteraan umum.

Lebih lanjut Bagir Manan menjelaskan bahwa yang dimaksud dengan tugas-tugas penyelenggaraan pemerintahan yang bersifat khusus adalah penyelenggaraan tugas dan wewenang pemerintahan secara konstitusional ada pada Presiden pribadi yang memiliki sifat prerogative di bidang pemerintahan. ${ }^{10}$

Dari uraian tersebut diatas jelaslah, bahwa administrasi negara itu sama artinya dengan pemerintahan, ${ }^{11}$ seringkali juga disebut eksekutif. Dalam pada itu dengan mengacu pada W. Ansley, Ismail Sunny mengatakan bahwa kekuasaan eksekutif adalah kekuasaan dalam negara yang melaksanakan undang-undang, menyelenggarakan urusan pemerintahan dan mempertahankan tata tertib serta keamanan, baik dalam maupun luar negeri.

9 Bagir Manan, Lembaga Kepresidenan, Gama Media, Yogyakarta, 1999, hal. 121-122

10 Ibid. hal.128

11 AD. Belinfante, Pokok - Pokok Hukum Tata Usaha Negara, Binacipta, 1983, hal.1 jUga Philipus M. Hadjon dkk, Pengantar Hukum Administrasi Indonesia, Gajahmada University Press, Yogyakarta, 1993, hal.26-27 
Dari keterangan tersebut di atas dapat disimpulkan, bahwa kekuasaan pemerintahan atau kekuasaan eksekutif pada dewasa ini tidak dapat dikatakan berfungsi hanya melaksanakan undangundang yang telah ditetapkan oleh badan legislatif. Sebagaimana telah disinggung di halaman muka, bahwa lingkup tugas dan wewenang penyelenggaraan pemerintahan negara semakin meluas sejalan dengan makin meluasnya tugas-tugas dan wewenang negara dan pemerintah. Hal demikian itu disebabkan oleh karena perkembangan masyarakat modern yang sangat pesat dan dinamis, dan ditunjang pula oleh kemajuan teknologi informasi dan komunikasi.

"Pemerintahan" demikian Van Poelje mengungkapkan harus melaksanakan undang-undang, tetapi melaksanakan undang-undang tidak berarti hanya melaksanakan semata-mata apa yang telah ditentukan oleh pembentuk undangundang. Hal ini lebih berarti mencari cara bagaimana dalam melaksanakan undang-undang, karena dalam pelaksanaannya tidak ditegaskan oleh pembentuk undang-undang sendiri. ${ }^{12}$ Dalam pada itu H.W.R. Wade mengatakan bahwa penyelenggara pemerintahan telah memegang inisiatif dan dapat mengambil sendiri pelbagai macam tugastugas baru, dan bersamaan dengan pengambilan sendiri tugas-tugas baru itu muncullah kekuasaankekuasaan baru. ${ }^{13}$

Kemudian selanjutnya, Pasal 5 ayat (1) UUD 1945 menyebutkan bahwa Presiden memegang kekuasaan membentuk undang-undang dengan persetujuan DPR. Penjelasan UUD ini menjelas-

12 R.Crince le Roy, Kekuasaan Keempat, Suatu Pengenalan Ulang, Penerbit Yayasan Dharma Bakti Semarang (tanpa tahun), hal.73 (terjemah oleh Soehardjo Ss, SH) kan bahwa kecuali "Executive Power" Presiden bersama DPR menjalankan "Legislative Power" dalam Negara. Presiden ialah kepala kekuasaan eksekutif dalam negara. Untuk menjalankan undang-undang ia mempunyai kekuasaan untuk menetapkan Peraturan Pemerintah ("Pouvoir Reglementair').

Dewan Perwakilan Rakyat diatur dalam Bab VII UUD 1945 (lama). bab ini meliputi Pasal-pasal 19, 20, 21 dan Pasal 22. Dari pasal-pasal tersebut disebutkan antara lain: susunan DPR ditetapkan dengan undang-undang, tiap-tiap undang-undang menghendaki persetujuan DPR.

Kemudian selanjutnya, dalam Bab IX diatur tentang kekuasaan Kehakiman. Bab ini meliputi Pasal 24 dan Pasal 25 (lama), Pasal 24 menetapkan: kekuasaan Kehakiman dilakukan oleh sebuah Mahkamah Agung dan lain-lain badan kehakiman menurut undang-undang. Dan dalam Pasal 25 ditegaskan bahwa syarat-syarat untuk menjadi dan untuk diberhentikan sebagai hakim ditetapkan dengan undang-undang.

Dari mana wewenang atau kekuasaan penyelenggara pemerintahan diperoleh?

Menurut R. Crince le Roy ${ }^{14}$ pemberian kewenangan dapat dilakukan melalui atribusi, delegasi dan mandat. Ketiga bentuk hukum tersebut harus dibedakan satu dengan yang lain. Dikatakan sebagai atribusi, apabila suatu ketentuan memberikan suatu kewenangan pemerintahan kepada suatu badan pemerintahan. Demikian maka suatu undang-undang dapat memberikan kewenangan kepada Mahkota atau kepada seorang menteri atau-

13 H.W.R Wade, Administrative Law, Clarendon Press, Oxford, 1971, hal 1 Juga Van Poeljo, Algemen.

14 R. Crince le Roy, Op. Cit. hal.89 
pun kepada pejabat untuk memberikan ijin tertentu. Disebut delegasi kewenangan pemerintahan, apabila suatu badan pemerintahan menyerahkan kewenangan yang ia peroleh melalui atribusi kepada badan pemerintahan yang lain, yang akan melaksanakannya menurut pendapatnya sendiri. Yang akhirnya adalah tentang bentuk mandat, juga di sini dapat dikatakan adanya suatu penyerahan kewenangan pemerintahan tetapi pelaksanaan tersebut tetap dilakukan atas nama dan di bawah tanggung jawab orang yang menyerahkan kewenangan itu.

Berkaitan dengan hal itu, Ridwan HR mengutarakan bahwa seiring dengan pilar utama $\mathrm{Ne}$ gara Hukum yaitu Asas Legalitas (Legaliteit Beginsel atau Het Beginsel Van Wetmatigheid Van Bestuur), maka berdasarkan prinsip ini tersirat bahwa wewenang pemerintahan berasal dari peraturan perundang-undangan artinya sumber wewenang bagi pemerintah adalah peraturan perundangundangan. ${ }^{15}$ Dikatakan bahwa secara teoritik kewenangan yang bersumber dari peraturan perundang-undangan tersebut diperoleh melalui tiga cara yaitu atribusi, delegasi dan mandat.

Dan uraian tersebuit di atas dapat disaring kesimpulan bahwa penyelenggara pemerintahan dan aparatur negara/Presiden memperoleh kewenangan dari atribusi, delegasi dan mandat. Dengan kata lain, Presiden mendapat kekuasaan/kewenangan pemerintahan yang bersumber pada UUD, ketetapan MPR, Undang-undang, Peraturan Pemerintah, dan Peraturan Perundang-undangan lainnya.

15 Ridwan HR, Hukum Administrasi Negara, Penerbit UII Press, Yogyakarta, 2003, hal.73

\section{Pembatasan-pembatasan Konstitusional Ke- kuasaan Presiden}

Sesudah perubahan UUD 1945, Presiden dan Wakil Presiden dalam satu pasangan secara langsung oleh Rakyat (Pasal 6A ayat (1)). Sementara itu Majelis Permusyawaratan Rakyat telah mereduksi sendiri kewenangannya menjadi sebagai berikut, Pasal 3:

(1) MPR mengubah dan menetapkan UUD;

(2) MPR melantik Presidan dan/atau Wakil Presiden;

(3) MPR hanya dapat memberhentikan Presiden dan/atau Wakil Presiden dalam jabatannya menurut UUD

Dari uraian tersebut di atas dapat diketahui, bahwa MPR tidak lagi memegang kekuasaan negara yang tertinggi, dan Presiden tidak lagi tunduk dan bertanggung jawab kepada Majelis.

Kemudian selanjutnya atas dasar UUD perubahan kekuasaan legislatif diberikan ke DPR, tidak ke MPR ataupun Badan Perwakilan Daerah (lembaga baru). Hal itu sesuai dengan bunyi Pasal 20 ayat (1) UUD 1945 perubahan: DPR memegang kekuasaan membentuk undang-undang. Demikianlah maka Presiden tidak lagi memegang kekuasaan membentuk undang-undang dengan persetujuan DPR akan tetapi hanya diberi hak inisiatif untuk mengajukan Rancangan UU (RUU) ke DPR.

Berkaitan dengan hal itu Denny Indrayana mengatakan bahwa pengalihan kekuasaan eksekutif ketangan DPR sudah benar, karena dengan demikian kekuasaan legislatif berada ditangan yang semestinya. ${ }^{16}$ Dalam pada itu Bagir Manan berpendapat bahwa amandemen ini mengukuhkan

16 Denny Indrayana, Op. Cit, hal.196 
checks and balances yang lebih jelas antara Presiden selaku lembaga eksekutif dan DPR sebagai Legislatif. ${ }^{17}$ Ditempat lain dikatakannya, bahwa perumusan baru Pasal 5 ayat (1) itu lebih memuaskan, karena terhindar dari kemungkinan salah pengertian mengenai kedudukan DPR sebagai pembentuk undang-undang. ${ }^{18}$

Dari uraian tersebut di atas dapat diketahui, bahwa kini telah terjadi pergeseran kekuasaan legislatif dari tangan Presiden ke DPR. Berkaitan dengan hal ini Maria Farida Indrati S. Mengemukakan pendapatnya bahwa berdasarkan ketentuan-ketentuan dalam UUD 1945 perubahan yang berkaitan dengan sistem pemerintahan negara tersebut, maka dapat disimpulkan bahwa kewenangan pembentukan undang-undang dilaksankan oleh DPR dengan persetujuan bersama Presiden. Dengan demikian dapat disimpulkan pula katanya lebih lanjut, bahwa Presiden Negara Republik Indonesia adalah pemegang kekuasaan dalam arti kekuasaan eksekutif dan kekuasaan membentuk undang-undang dalam arti legislatif bersama Dewan Perwakilan Rakyat. ${ }^{19}$

Pandangan yang sama dikemukakan oleh Denny Indrayana, yang menyatakan, ${ }^{20}$ bahwa Presiden asih tetap memiliki kekuasaan legislatif yang signifikan. Dikatakan lebih lanjut, bahwa RUU dibahas dan harus disetujui oleh DPR maupun Presiden, syarat persetujuan Presiden ini pada dasarnya merupakan "hak veto" bagi Presiden.

Pasal 7 UUD 1945 telah mengalami perubahan pula dalam tahun 1999-2002 itu perumusan baru Pasal 7 itu berbunyi: Presiden dan Wakil

17 Bagir Manan, DPR, DPD dan MPR dalam UUD 1945 Baru, FH.UII Yogyakarta, 2005, hal. 20-22

18 Bagir Manan, Perkembangan..., op cit, hal.28
Presiden memegang jabatan selama lima tahun dan sesudahnya dapat dipilih kembali dalam jabatan yang sama hanya untuk satu kali masa jabatan. Perubahan Pasal 7 ini telah didahului oleh ketetapan MPR No. XIII/MPR/1998 mengenai hal yang sama. Perubahan Pasal 7 ini dimaksudkan untuk mencegah praktik pemilihan kembali seseorang sebagai Presiden berkali-kali tanpa batas waktu, seperti yang terjadi pada Presiden Soeharto. Berdasarkan ketentuan baru ini seorang hanya dapat menjabat Presiden atau Wakil Presiden paling lama sepuluh tahun. Demikian itu dengan klausula: “... dan sesudahnya dapat dipilih kembali" yang harus diartikan sebagai sepuluh tahun berturut-turut.

Sesudah perubahan UUD 1945 telah dibentuk beberapa lembaga atau badan, antara lain: Mahkamah Konstitusi dan Komisi Yudisial, keduanya di lingkungan kekuasaan kehakiman. Mahkamah Konstitusi merupakan pelaku kekua-saan bersama dengan Mahkamah Agung, untuk menyelenggarakan peradilan guna menegakkan hukum dan keadilan (Pasal 24 ayat 1 dan 2). Mahkamah Konstitusi mempunyai sembilan orang anggota hakim konstitusi yang ditetapkan oleh Presiden, yang diajukan masing-masing 3 orang oleh Mahmkamah Agung. Tiga orang Dewan Perwakilan Rakyat dan tiga orang oleh Presiden (Pasal $24 \mathrm{C}$ ayat 3)

Mahkamah Konstitusi diberi wewenang mengadili pada tingkat pertama dan terakhir yang putusannya bersifat final:

19 Maria Farida Indrati S., IImu Perundang -undangan,

20 Denny Indrayana, Op. Cit., hal. 377 
1. Untuk menguji undang-undang terhadap Undang-Undang Dasar;

2. Memutus sengketa wewenang lembaga negara yang kewenangannya diberikan oleh Undang-Undang Dasar;

3. Memutuskan pembubaran partai politik; dan

4. Memutuskan perselisihan tentang hasil Pemilihan Umum (Pasal 24C ayat (1))

Ditambah satu "wewenang" lagi, yakni: wajib memberikan putusan atas pendapat DPR atas dugaan pelanggaran oleh Presiden dan/atau Wakil Presiden menurut UUD (Pasal 24C ayat (2))

Komisi Yudisial bersifat mandiri yang berwenang mengusulkan pengangkatan hakim agung dan mempunyai wewenang lain dalam rangka menjaga dan menegakkan kehormatan, keluhuran martabat, serta perilaku hakim. Anggota Komisi Yudisial diangkat dan diberhentikan oleh Presiden dengan persetujuan Dewan Perwakilan Rakyat (Pasal 24B ayat 1 dan 3). Pasal 24A ayat (3) menyebutkan: "Calon Hakim Agung diusulkan Komisi Yudisial kepada Dewan Perwakilan Rakyat untuk mendapatkan persetujuan dan selanjutnya ditetapkan sebagai Hakim Agung oleh Presiden.

Demikian jelaslah bahwa kini Hakim Agung tidak lagi diangkat oleh Presiden, melainkan diajukan oleh Komisi Yudisial untuk diminta persetujuan DPR, untuk kemudian ditetapkan oleh Presiden. Hal yang sama juga anggota Badan Pemeriksaan Keuangan tidak lagi diangkat oleh Presiden, tetapi dipilih oleh DPR dengan memperhatikan Dewan Perwakilan Rakyat dan diresmikan oleh Presiden (Pasal 23F ayat 1).

Pasal 10 UUD 1945 termasuk dalam pasal yang tidak mengalami perubahan, menga- manatkan: Presiden memegang kekuasaan yang tertinggi atas Angkatan Darat, Angkatan Laut dan Angkatan Udara. Dalam hal pengerahan kekuatan Tentara Nasional Indonesia (TNI) Presiden harus mendapat persetujuan DPR, kecuali dalam keadaan memaksa untuk menghadapi ancaman militer dan/atau ancaman bersenjata Presiden dapat langsung mengerahkan kekuatan TNI; dengan syarat bahwa dalam waktu 2x24 jam terhitung sejak dikeluarkannya keputusan pengerahan kekuatan, Presiden harus melaporkan ke DPR. Dan apabila DPR tidak menyetujuinya, maka Presiden harus menghentikan pengerahan kekuatan TNI tersebut. Tanggung jawab penggunaan kekuatan TNI berada pada Panglima TNI (UU No. 34 Tahun 2014 Pasal 17, 18 dan Pasal 19).

Berdasarkan Undang-undang Pertahanan Negara tahun 2002 No.3 Panglima TNI diangkat dan diberhentikan oleh Presiden dengan persetujuan DPR (Pasal 17). Demikian pula halnya dengan Kepala Kepolisian Negara Republik Indonesia (Kapolri) diangkat dan diberhentikan oleh Presiden dengan persetujuan DPR (UU No: 2 Tahun 2002 Pasal 11).

Berdasarkan uraian tersebut di atas dapatlah diketahui, bahwa dalam pengarahan kekuatan TNI dan pengangkatan Panglima TNI dan Kapolri selalu dilibatkan peranan DPR dalam penyelenggaraan negara. Menurut Taufiqurrohman Syahuri, keterlibatan DPR dalam hal pengangkatan pejabat-pejabat tersebut mencerminkan suatu mekanisme ketatanegaraan yang mengarah kepada keseimbangan dan demokratisasi. Menurut hemat penulis keterlibatan DPR termaksud guna melakukan "Fit and Proper Test" adalah khususnya untuk menentukan pejabat yang 
amat sesuai dan tepat, merupakan metode atau cara yang amat baik. Pada saat ini sudah barang tentu tidak mungkin menentukan pejabat tinggi yang sesuai dan tepat untuk jabatan yang tersedia, melalui metode atau cara misalnya dengan ujian atau dengan psycho test, masa percobaan, atau waktu dinas yang panjang. Pejabat tinggi membutuhkan fantasi yang konstruktif dan kemampuan berpikir elastis atau dengan perkataan lain untuk menentukan pejabat-pejabat tinggi yang memiliki integritas dan kepribadian tidak tercela.

Kemungkinan selanjutnya dengan persetujuan DPR menyatakan perang, membuat perdamaian dan perjanjian dengan negara lain. Presiden dalam membuat perjanjian internasional lainnya yang menimbulkan akibat yang luas dan mendasar bagi kehidupan rakyat yang terkait dengan beban keuangan negara dan/atau mengharuskan perubahan atau pembentukan undang-undang, harus dengan persetujuan DPR (Pasal 11 ayat 1 dan 2 UUD 1945 Perubahan). Kekuasaan diplomatik Presiden mengalami pula pembatasan dan memberi DPR lebih banyak hak kontrol dalam pengangkatan duta besar, konsul dan dalam menerima duta besar negara-negara asing. Kekuasaan Presiden ini harus digunakan dengan memperhatikan pertimbangan DPR (Pasal 13 ayat 1 dan 2 UUD 1945 Perubahan).

Berkaitan dengan hal itu, Jimly Asshiddiqie menyatakan bahwa Pasal ini tidak praktis dan melanggar kelaziman dalam diplomasi Internasional. Hal ini berbahaya karena dapat melahirkan sebuah sistem diplomasi yang kurang efisien. ${ }^{21}$

21 Jimly Asshiddiqie dikutip pada Denny Indrayana, Op. Cit., hal. 369

22 Fajrul Falaakh dikutip pada Denny Indrayana, Loc. Cit.
Seperti rekannya Fajrul Falaakh menyatakan bahwa syarat pertimbangan DPR dalam pengangkatan duta besar merupakan intervensi berlebihan lembaga legislatif dalam urusan eksekutif. ${ }^{22}$ Pendapat senada dikemukakan Bagir Manan dikatakan hal ini pun (penempatan duta negara lain, pen) tidak semestinya dicampuri DPR. Duta besar suatu negara asing adalah wakil negara yang bersangkutan yang diangkat berdasarkan syarat-syarat dari negara yang bersangkutan. Selain itu penunjukan seorang duta besar negara asing telah memperoleh "persetujuan" Pemerintah RI (Presiden). Dikatakan lebih lanjut, bahwa menempatkan pertimbangan DPR sebagai fungsi kontrol terhadap hal semacam ini sangat berlebihan, mengingat segala bentuk hubungan luar negeri ada dalam lingkup kekuasaan eksekutif dan Presiden adalah "Penguasa Tunggal" hubungan luar negeri. ${ }^{23}$

Dalam hubungan ini Denny Indrayana menuturkan bahwa satu kasus khusus antara Indonesia dan Australia sangat mempengaruhi perancangan amandemen ini. ${ }^{24}$ Dikatakan pada tahun 1995 pemerintah Australia menolak pengangkatan HBL Mantiri sebagai duta besar Indonesia untuk Australia dengan alasan bahwa yang bersangkutan pernah mendukung TNI dalam pembantaian di Santa Cruz, Timor Timur 12 November 1991.

Diutarakannya lebih lanjut, bahwa amandemen lain yang bertalian dengan peristiwa-peristiwa sebelumnya adalah yang membatasi kekuasaan Presiden untuk memberi gelar, tanda jasa dan tanda-tanda kehormatan lainnya (Pasal 15) juga dipicu oleh tindakan Habibie yang membagi-

\footnotetext{
23 Bagir Manan, Perkembangan..., Op. Cit, hal.30-31

24 Denny Indrayan, Op. Cit, hal.198
} 
bagi tanda kehormatan kepada pendukungpendukungnya pada bulan Agustus 1999. Pasal 15 UUD 1945 Perubahan itu berbunyi: "Presiden memberi gelar, tanda jasa, dan lain-lain tanda kehormatan yang diatur dengan undang-undang".

Pembatasan kekuasaan yudisial Presiden

(Pasal 14 ayat 1 dan 2) menyatakan bahwa Presiden harus berkonsultasi terlebih dahulu dengan Mahkamah Agung sebelum memberikan grasi dan rehabilitasi. Selain itu juga mengharuskan Presiden mendengar saran-saran DPR sebelum memberikan amnesti dan abolisi. Dalam hal ini perlunya pertimbangan Mahkamah Agung karena masalah grasi, amnesti, abolisi dan rehabilitasi berkaitan dengan persoalan hukum, tidak terutama persoalan politik. Dalam praktek ketatanegaraan (seperti diatur dalam UU Mahkamah Agung) grasi memerlukan pertimbangan Mahkamah Agung. Mengikut sertakan DPR dalam amnesti dan abolisi, dapat diperkirakan berdasarkan asumsi karena amnesti dan abolisi sebagai tindakan politik. Hal ini agak ganijil karena amnesti, abolis, rehabilitasi termasuk grasi adalah hak konstitusional Presiden yang lazim disebut hak prerogatif. Dikatakan semestinya penggunaan hak tersebut tidak dicampuri oleh lembaga lain, pertimbangan grasi oleh Mahkamah Agung karena menyangkut putusan pengadilan. ${ }^{25}$

Dalam pelbagai peraturan perundang-undangan diatur pula pembatasan-pembatasan terhadap kekuasaan Presiden dan memberi hak kontrol kepada DPR.

Undang-undang No. 23 Tahun 1999 menyatakan bahwa Gubernur dan Deputi Gubernur Senior diusulkan dan diangkat oleh Presiden dengan persetujuan DPR. Demikian pula Deputi Gubernur diusulkan oleh Gubernur dan diangkat oleh Presiden dengan persetujuan DPR (Pasal 41 ayat 1 dan 2). Undang-undang menetapkan bahwa Pemilihan Umum diselenggarakan oleh Komisi Pemilihan Umum (KPU) yang bersifat nasional, tetap dan mandiri, calon anggota KPU diusulkan oleh Presiden untuk mendapat persetujuan DPR., untuk ditetapkan sebagai anggota Komisi Pemilihan Umum (Pasal 19 ayat 1).

Undang-undang No. 37 Tahun 2008 mengatakan bahwa Ombudsman berfungsi mengawasi penyelenggaraan pelayanan publik yang diselenggarakan oleh Penyelenggara Negara dan Pemerintah, baik dipusat maupun didaerah, termasuk yang diselenggarakan oleh Badan Usaha Milik Negara, Badan Usaha Milik Daerah dan Badan Hukum Milik Negara serta badan swasta atau perseorangan yang diberi tugas menyelenggarakan pelayanan publik tertentu. Ketua, Wakil Ketua dan Anggota Ombudsman dipilih oleh Dewan Perwakilan Rakyat berdasarkan calon yang diusulkan oleh Presiden dan disahkan oleh Presiden.

Anggota Komisi Nasional Hak Asasi Manusia berjumlah 35 (tiga puluh lima) orang yang dipilih oleh Dewan Perwakilan Rakyat berdasarkan usuIan Komisi Nasional Hak Asasi Manusia dan diresmikan oleh Presiden selaku Kepala Negara (UU No. 39 Tahun 1999 Pasal 81 ayat 1). Undangundang No. 23 Tahun 2002 tentang Perlindungan Anak menyebutkan bahwa dalam rangka meningkatkan efektivitas penyelenggaraan perlindungan

25 Bagir Manan, Perkembangan..., Op. Cit., hal. 35 
anak, dengan undang-undang ini dibentuk Komisi Perlindungan Anak Indonesia (KPAl) yang bersifat independen. Keanggotaan Komisi Perlindungan Anak Indonesia diangkat dan diberhentikan oleh Presiden, setelah mendapat pertimbangan DPR (Pasal 74 dan Pasal 75 ayat 3).

Peraturan Pemerintah No. 12 Tahun 2005 menetapkan bahwa Dewan Pengawas Lembaga Penyiaran Publik Radio Republik Indonesia ditetapkan adalah Presiden atas usul DPR-RI setelah melalui uji kepatuhan dan kelayakan oleh DPR-RI secara terbuka atas masukan dari pemerintah dan/ atau masyarakat. Pasal 19 ayat (1) Peraturan Pemerintah No. 13 tahun 2005 menetapkan bahwa Dewan Pengawas Lembaga Penyiaran Publik Televisi Republik Indonesia ditetapkan adalaah Presiden atas usul Dewan Perwakilan Rakyat setelah melalui uji kepatuhan dan kelayakan oleh DPR. Calon anggota Komisi Informasi Pusat diajukan kepada DPR oleh Presiden, untuk dipilih melalui uji kepatutan dan kelayakan. Anggota Komisi Informasi Pusat yang telah dipilih oleh DPR selanjutnya ditetapkan oleh Presiden (UU No. 14 Tahun 2008 Pasal 31)

Pasal 10 Undang-undang No. 28 Tahun 1999 menyebutkan bahwa untuk mewujudkan penyelenggara negara yang bersih dan bebas dari korupsi, kolusi dan nepotisme. Presiden selaku Kepala Negara membentuk Komisi Pemeriksa, komisi ini merupakan lembaga independen yang bertanggungjawab langsung kepada Presiden selaku Kepala Negara. Komisi Pemeriksa mempunyai fungsi mencegah praktik korupsi, kolusi dan nepostime dalam penyelenggaraan negara dengan mela- kukan pemeriksaan terhadap kekayaan penyelenggara negara baik sebelum, selama dan setelah yang bersangkutan menjabat. Pengangkatan dan pemberhentian Anggota Komisi Pemeriksa ditetapkan dengan Keputusan Presiden setelah mendapat persetujuan Dewan Perwakilan Rakyat (Pasal 13 ayat 2). Undang-undang No. 30 Tahun 2002 memberi hak kontrol kepada Dewan Perwakilan Rakyat untuk memilih/menyeleksi pimpinan Komisi Pemberantasan Korupsi Rakyat untuk memilih/menyeleksi pimpinan Komisi Pemberantasan Korupsi berdasarkan calon anggota yang diusulkan oleh Presiden. Calon terpilih disampaikan oleh pimpinan DPR kepada Presiden untuk disahkan oleh Presiden selaku Kepala Negara (Pasal 30 ayat 1 )

Demikian selanjutnya UU No. 8 tahun 1999 tentang Perlindungan Konsumen menetapkan bahwa anggota Badan Perlindungan Konsumen Nasional diangkat dan diberhentikan oleh Presiden atas usul menteri setelah dikonsultasikan kepada DPR-RI.

\section{Penutup}

Simpulan

Sesudah perubahan UUD 1945, terjadi pergeseran kekuasaan legislatif dari tangan Presiden ke Dewan Perwakilan Rakyat. Kekuasaan Presiden bayak dikurangi, sementara kekuasaan pada Dewan Perwakilan Rakyat diperbesar sedemikian rupa sehingga praktis semua bidang kekuasaan Presiden dimasuki oleh DPR 26 
Adnan Buyung Nasution mengatakan, bahwa sistem presidential yang kita anut sekarang ini tidak akan cukup mampu mengakomodasi berbagai permasalahan bangsa yang begitu besar dan kompleks dengan wilayah negara yang begitu luas. Oleh karena itu kekuasaan dan tanggungjawab politik mustahil dikonsentrasikan hanya pada satu orang. Dikatakan apalagi kekuasaan Presiden sekarang ini, setelah amandemen UUD 1945 telah mengalami pembatasan-pembatasan yang berlebihan untuk berjalannya sistem presidential yang efektif dan efisien serta akuntabel.

Pada saat ini kekuasaan pada DPR sudah diperbesar, Denny Indrayana menyebutkan sejak amandemen Dewan Perwakilan Rakyat menjadi sebuah lembaga legislatif yang digdaya. Menurut Saldi Isra, amandemen-amandemen itu bahkan telah melahirkan DPR yang unggul dan dengan begitu konstitusi sudah berubah dari sebuah konstitusi yang sarat eksekutif menjadi konstitusi yang sarat DPR.

Wewenang besar yang dijalankan oleh administrasi berdasarkan perintah yang sah, dimana-mana menimbulkan panggilan untuk mengadakan pengawasan terhadap administrasi untuk memberikan perlindungan hukum bagi rakyat. Harus diupayakan agar jangan sampai pihak yang seharusnya dikontrol justru mengontrol pihak yang seharusnya mengontrolnya. Apabila ini terjadi, maka kepastian hukum serta tertib administrasi akan mejadi kehilangan makna. ${ }^{27}$

26 Adnan Buyung Nasution, "Relasi Kekuasaan Legislatif dan Presiden Pasca Amandemen UUD 1946: Sistem Semi Presidential dalam Proyeksi", Jurnal Hukum, No. 28 Vol.12 Januari 2005, FH-UII Press, Yogyakarta, hal.5
Saran

Agar kekuasaan tidak disalahgunakan, maka harus diatur batas-batasnya, caranya dengan membagi kekuasaan tersebut kedalam ketiga cabang kekuasaan secara seimbang.

\section{DAFTAR PUSTAKA}

Buku

Atmosudirjo, Prajudi. Dasar - Dasar IImu Administrasi. Cet. Ke 7. Jakarta. 1979.

Belifante, AD. Pokok-Pokok Hukum Tata Usaha Negara, Binacipta. Jakarta. Terjemahan: Boerhanoeddin Soetan Batoeah. 1983.

Crince le Roy, R., Kekuasaan Ke-empat, Suatu Pengenalan Ulang, Yay. Dharma Bhakti, tanpa tahun. Terjemahan: Soehardjo, Ss.

Indrayana, Denny. Amandemen UUD 1945, Antara Mitos dan Pembongkaran, PT. Mizan Pustaka, Bandung, 2007.

Hadjon, Philipus M., dkk. Pengantar Hukum Administrasi Indonesia, GAMA University Press, Yogyakarta, 1993.

Kusnardi, Moh. dan Bintang R. Saragih, Susunan Pembagian Kekuasaan Menurut UUD 1945, Gramedia, Jakarta, 1978.

Manan, Bagir. DPR, DPD dan MPR dalam UUD 1945 Baru. FH.UII. Yogyakarta. 2005.

------, Lembaga Kepresidenan. GAMA Media. Yogyakarta. 1999.

------, Perkembangan UUD 1945. UII Press. Yogyakarta. 2004.

Maria Farida Indradi S, Ilmu PerundangUndangan, Penerbit Kanisius, Yogyakarta, 2007.

Poelje, Van, Algemene Inleiding tot de Bestuurskunde, Cet. Ke 3.

Ridwan, HR, (2003). Hukum Administrasi Negara. Ull-Press. Yogyakarta.

27 Koerniatmanto Soetoprawiro, "Tantangan IImu Hukum administrasi Menghadapi Pekembangan Konsep Negara Hukum di Indonesia", Majalah Hukum PRO JUSTITIA, Thn.X No. 4 Oktober 1992, FH. Unpar, Bandung, hal.13. 
Wade. HWR. Administrative Law. Clarenden Press. Oxford. 1971.

Wiyono. R.. Garis-Garis Besar Pembahasan dan Komentar UUD 1945. Penerbit Alumni. Bandung. 1982.

Wynes. Ansley. W.. Legislatif. Executive and Judicial Power in Australia.

\section{Jurnal}

Adnan Buyung Nasution. Relasi Kekuasaan Legislatif dan Presiden Pasca Amandemen UUD 1945: Sistem Semi Presidensial dalam Proyeksi. dalam Jurnal Hukum No. 28 Vol. 12 Januari 2005. UII-Press. Yogyakarta.

Soetoprawiro. Koerniatmanto. Tantangan IImu Hukum Administrasi Menghadapi Perkembangan Konsep Negara Hukum di Indonesia. dalam Majalah Hukum Pro Justicia. Thn. X No. 4. Oktober 1992. FH. Unpar. Bandung. 